\title{
PENGARUH MEDIA SOSIAL TERHADAP PERILAKU KONSUMTIF MAHASISWA
}

\section{THE INFLUENCE OF SOCIAL MEDIA ON CONSUMPTIVE BEHAVIOR OF STUDENTS}

\author{
Dede Mustomi $^{1^{* *}}$ Aprilia Puspasari $^{2)}$ \\ ${ }^{1}$ Administrasi Bisnis, Fakultas Ekonomi dan Bisnis, Universitas Bina Sarana Informatika \\ ${ }^{2}$ Sistem Informasi Akutansi, Fakultas Teknologi Informasi, Universitas Bina Sarana \\ Informatika \\ ${ }^{1}$ Email: dede.ddo@bsi.ac.id
}

\begin{abstract}
ABSTRAK
Penelitian ini bertujuan untuk melihat bagaimana media sosial mempengaruhi gaya hidup mahasiswa. Fokus penelitian ini menilai dari sisi perilaku konsumtif mahasiswa dengan hadirnya media sosial. Ada dua variabel uang akan diuji dalam artikel ini, variabel bebas media sosial dan variabel terikat perilaku konsumtif mahasiswa. Artikel ini menggunakan metode correlation pearson untuk mengolah data korelasi atau hubungan antara media sosial terhadap perilaku konsumtif mahasiswa. Pengumpulan data menggunakan metode survei yakni dengan menyebar kuesioner kepada 81 responden. Responden yang dipilih adalah mahasiswa. Data kuesioner responden diuji untuk mengetahui kevalidan data angket. Data kuesioner juga diuji reliabilitasnya untuk mengetahui konsistensinya. Semua data responden diolah menggunakan SPSS versi 22. Hasil uji validitas semua data kuesioner dinyatakan valid dengan nilai $r$ hitung lebih tinggi dari $r$ tabel. Hasil uji reliabilitas semua data kuesioner dinyatakan reliabel dengan nilai alpha lebih besar dari $r$ tabel. Hasil uji korelasi variabel X terhadap Variabel Y dengan menggunakan correlation pearson. Hasilnya tidak ada pengaruh signifikan antara media sosial terhadap perilaku konsumtif mahasiswa.
\end{abstract}

Kata kunci: Media Sosial, Perilaku, Konsumtif

\begin{abstract}
This study aims to see how social media influences student lifestyles. The focus of this study assesses in terms of the consumptive behavior of students with the presence of social media. There are two variables of money to be tested in this article, the independent variable is social media and the dependent variable is the consumptive behavior of students. This article uses the Pearson correlation method to process correlation data or the relationship between social media and student consumptive behavior. Data collection using survey methods by distributing questionnaires to 81 respondents. The selected respondents were students. Respondent questionnaire data was tested to determine the validity of the questionnaire data. The questionnaire data was also tested for its reliability to determine its consistency. All respondent data were processed using SPSS version 22. The results of the validity test of all questionnaire data were declared valid with $r$ counts higher than $r$ tables. The reliability test results of all questionnaire data were declared reliable with alpha values greater than $r$ table. The results of the correlation test of variable $X$ to variable $Y$ using Pearson correlation. The result is that there is no significant influence between social media on the consumptive behavior of students.
\end{abstract}


P-ISSN 2580 - 7781

E-ISSN 2615 - 3238

Keywords: Social Media, Behavior, Consumptive

\section{PENDAHULUAN}

Informasi dan teknologi adalah dua faktor yang tidak hanya membawa perubahan dalam dunia e-commerce tetapi juga merevolusi cara bisnis dilakukan online (Das, 2014). Integrasi Internet yang serba cepat sebagai alat pemasaran dalam beberapa tahun terakhir telah berdampak besar pada bagaimana berkomunikasi dengan pelanggan mereka dan internet telah menyediakan platform besar untuk merek lokal dan global untuk memperluas pasar mereka dan memperoleh lebih banyak pelanggan dari pada sebelumnya (POTURAK \& SOFTIĆ, 2019). Dengan meningkatnya jejaring sosial, era baru penciptaan konten telah muncul, di mana individu dapat dengan mudah berbagi pengalaman dan informasi dengan pengguna lain (Chen et al. 2011a dalam Hajli, 2013).

Istilah media sosial dapat didefinisikan sebagai penggunaan berbasis web dan seluler teknologi untuk mengubah komunikasi dengan pengguna media sosial lainnya, termasuk klien perusahaan, menjadi dialog interaktif (Perdana, 2018). Komunikasi elektronik khususnya media sosial mengubah lanskap perdagangan dan cara komunikasi antara perusahaan dan pelanggan (Delafrooz, Zendehdel, \& Fathipoor, 2017). Perusahaan dapat menggunakan media sosial untuk membangun interpersonal lebih lanjut hubungan dengan pelanggan (Delafrooz et al., 2017). Setiap platform media sosial berperan dalam memberikan, menerima, dan bertukar informasi tanpa batasan dan sebagaimana disebutkan sebelumnya bahwa media sosial memungkinkan aliran informasi dua arah (Lee, 2013). Media sosial telah mentransformasi dan menggabungkan diri ke dalam perkembangan media baru (Solis, 2010 dalam Khatib, 2016). Media sosial mencakup proyek kolaboratif seperti Wikipedia, blog, komunitas konten seperti YouTube, situs jejaring sosial seperti Facebook, dunia sosial virtual seperti Second Life dan dunia game virtual seperti World of Warcraft (Kaplan dan Haenlein, 2010 dalam Khatib, 2016).

Media sosial merupakan alat komunikasi sederhana bagi orang untuk tetap berhubungan dengan teman dan kerabat (Pradeep \& Nair, 2018). Media sosial menyediakan ruang virtual bagi orang untuk berkomunikasi melalui internet, yang 
juga mungkin menjadi agen penting sosialisasi konsumen (Khatib, 2016). Media sosial telah menciptakan lanskap baru dalam mendukung sosialisasi informasi (Solis, 2007 dalam Khatib, 2016). Konsumen di dunia saat ini semakin bergantung pada internet untuk mendapatkan informasi tentang makanan untuk membandingkan berbagai alternatif pembelian dan memaksimalkan pengetahuan mereka sebelum membuat keputusan penting tentang pembelian makanan (Fathelrahman \& Basarir, 2018). Pengguna media sosial juga dianggap sebagai pembeli potensial, sehingga industri makanan sudah mulai memasarkan makanan secara online (Fathelrahman \& Basarir, 2018).

Pemasaran media sosial bukan lagi aspek baru, tetapi masih dianggap sebagai topik yang berkembang di lapangan (Khatib, 2016). Media sosial seperti Facebook, Twitter dan YouTube adalah alat dinamis yang memfasilitasi hubungan online (Voramontri \& Klieb, 2019). Meningkatkan hubungan pelanggan dengan mentransfer informasi baru ke pelanggan tentang acara khusus dan layanan baru menjadi ciri khas pemasaran lewat media sosial (Delafrooz et al., 2017).

Rasanya hampir semua masyarakat memiliki akun media sosial, meski Cuma satu akun media sosial. Media sosial bukan lagi tentang gaya hidup akan tetapi sudah menjadi kebutuhan yang tidak bisa dilepaskan dalam kehidupan sehari hari. Ada sejumlah media sosial yang memfasilitasi kegiatan ini, seperti Wikipedia, Facebook, YouTube dan Twitter. Individu menerapkan berbagai alat media sosial, seperti forum online dan komunitas untuk berinteraksi dengan pengguna lain secara online (Hajli, 2013).

Teknologi dapat mendekatkan posisi di antara orang-orang jauh lebih cepat daripada edisi sebelum ada teknologi digital (Delafrooz et al., 2017). Keputusan pembelian dapat diartikan sebagai tindakan yang dilakukan oleh konsumen untuk membeli atau menggunakan barang dan jasa(Empati et al., 2018).

Media sosial mengubah dunia kita. Melalui munculnya smartphone dan media sosial, aksesibilitas informasi lebih tinggi dari yang pernah ada sebelumnya. Pelanggan sering diminta untuk "suka" perusahaan di Facebook, untuk "mengikuti" perusahaan di Twitter, atau untuk "terhubung" via LinkedIn. 
Akibatnya, pelanggan menjadi lebih terhubung kepada perusahaan, lebih banyak pengetahuan tentang pilihan produk, (Agnihotri, Dingus, Hu, \& Krush, 2016).

Remaja yang hidup di zaman sekarang dihadapkan pada penawaran barang yang ditawarkan melalui media (Santrock 2011 dalam Empati et al., 2018). Studi menunjukkan, pelajar yang menghabiskan waktunya untuk mengakses internet akan berdampak pada lebih sedikit waktu belajar yang dihasilkan. Para mahasiswa menghabiskan waktu setiap hari menggunakan internet dengan gadget yang dimiliki, individu akan kehilangan waktu efektif dalam urusan akademik, minimal satu jam seminggu. Waktu yang dihabiskan mahasiswa untuk menggunakan internet bervariasi, mulai dari beberapa menit hingga lebih dari 1 jam. Dampak dari hal tersebut ialah nilai akademis mahasiswa menurun sangat drastis (Empati et al., 2018).

Perilaku konsumtif merupakan suatu tindakan yang dilakukan secara berlebihan terhadap penggunaan suatu produk. Lebih lanjut, perilaku konsumtif juga diartikan sebagai tindakan memakai suatu produk secara tidak tuntas. Artinya, seseorang membeli produk bukan karena produk yang dipakai telah habis, melainkan karena adanya iming-iming hadiah yang ditawarkan atau bahkan produk tersebut sedang trend (Anggraini \& Santhoso, 2019). Fenomena perilaku konsumtif ini tentunya akan terus berkembang, dikarenakan adanya faktor yang dapat menyebabkan munculnya perilaku konsumtif, salah satunya adalah gaya hidup (Anggraini \& Santhoso, 2019).

Pengertian konsumtif secara luas yaitu menggunakan barang atau jasa dengan cara berperilaku boros dan berlebihan yang lebih mendahulukan keinginan daripada kebutuhan dalam segi prioritas atau dapat juga dikatakan gaya hidup berlebihan (Empati et al., 2018). Fenomena yang terjadi saat ini menunjukkan bahwa masyarakat yang berperilaku konsumtif tidak melihat usia, jenis kelamin dan pekerjaan. Mereka bisa saja dari kaum remaja, dewasa dan orang tua namun beberapa penelitian melaporkan bahwa remaja cenderung berperilaku konsumtif (Widyaningrum \& Puspitadewi, 2016).

Ada istilah yang sering kita dengar, ada uang ada barang. Ketika uang melimpah dikantong kadang kala kita lupa diri dan lupa waktu, dengan membeli 
semua yang kita inginkan dan bukan yang kita butuhkan. Hal ini mencerminkan perilaku konsumtif diantara masyarakat kita. Kadang ketika pergi kepusat perbelanjaan, kita tidak merencakan apa yang akan kita beli, sehingga ketika sampai ditempat tujuan kita seperti kalap dengan membeli apa yang kita inginkan. Yayasan Lembaga Konsumen Indonesia memberikan batasan mengenai perilaku konsumtif sebagai kecenderungan seseorang dalam mengkonsumsi tanpa memiliki batasan, serta lebih mengedepankan faktor keinginan daripada kebutuhan (Anggraini \& Santhoso, 2019).

Penelitian menunjukkan keputusan pembelian terkait langsung dengan pengaruh pribadi, rujukan, atau media (Rizkallah \& Truong, 2010). Perilaku konsumtif adalah tindakan individu yang secara langsung terlibat dalam memperoleh dan menggunakan barang atau jasa dengan mendahulukan proses pengambilan keputusan. Predikat konsumtif biasanya melekat pada diri seseorang apabila seseorang tersebut membeli barang atau jasa diluar kebutuhan rasional (Widyaningrum \& Puspitadewi, 2016).

Fenomena yang terjadi di masyarakat perkotaan adalah budaya konsumtif yang tinggi, hal ini disebabkan oleh tingginya tingkat kebutuhan sehari hari yang dibutuhkan oleh manusia baik itu dari kalangan atas maupun dari kalangan bawah yang akan lebih selektif pada produk yang di konsumsi. Produk produk baru ditawarkan dan di informasikan dengan cepat yang nantinya akan mempengaruhi penawaran dan permintaan pasar (Mowen \& Minor, 2002 dalam Empati et al., 2018).

Telah banyak media sosial membantu kehidupan masyarakat, baik untuk kegiatan ekonomi maupun sosial, meski kita tidak bisa memungkiri media sosial juga tentu ada sisi negatifnya. Semua tergantung mereka yang menggunakannya.

Artikel ini fokus membahas sisi media sosial terhadap perilaku konsumtif mahasiswa. Kita ketahui bersama rasanya kehidupan ini semakin mudah dengan era digital. Membeli apapun cukup dengan menggunakan gadget. Tidak lagi perlu keluar rumah atau bepergian ketempat perbelanjaan. Bahkan untuk membeli makanan sekalipun cukup dari rumah ambil gadget dan pesan makanan, tidak butuh waktu lama makanan akan datang kerumah kita. Kemudahan kemudahan 
tersebut apakah menjadikan kita lebih konsumtif atau tidak. Artikel ini akan membahasnya bagaimana pengaruh media sosial terhadap perilaku konsumtif mahasiswa.

Artikel ini merujuk kepada jurnal internasionalyang ditulis oleh Pradeep \& Nair, 2018, yang berjudul Impact Of Social Media On Consumer Baying Decision Towards Financial Assets Among IT Professionals At Kepala. Tujuan artikel tersebut adalah Untuk memahami pengaruh media sosial terhadap pembelian produk keuangan oleh TI profesional di Kerala. Hipotesis yang digunakan yakni tidak ada hubungan yang signifikan antara pemasaran media sosial dan keputusan pembelian rencana penghematan oleh para profesional TI (Pradeep \& Nair, 2018).

Artikel yang saya tulis berjudul Pengaruh Media Sosial terhadap Perilaku Konsumtif Mahasiswa. Tujuan artikel untuk mengetahui apakah pemasaran lewat media sosial mempengaruhi tingkat konsumtif belanja mahasiswa. Hipotesis yang digunakan yakni tidak ada pengaruh signifikan antara media sosial terhadap perilaku konsumtif belanja mahasiswa.

\section{METODE PENELITIAN}

Metode penelitian yang digunakan ialah correlational research yang bertujuan untuk mendeteksi sejauh mana variasi-variasi pada suatu faktor berkaitan dengan variasi pada faktor lain berdasarkan koefisien korelasi. Studi korelasional menampilkan hubungan antara variabel dengan teknik seperti tabulasi silang dan korelasi. Correlational research adalah meneliti dengan menggunakan uji statistik korelasi untuk menggambarkan dan mengukur tingkat hubungan antara dua atau lebih variabel (Is, Should, \& Be, 2011).

Populasi yang digunakan adalah mahasiswa semester lima jurusan akutansi yang sudah bekerja diberbagai perusahaan. Teknik analisa data sampel responden untuk uji validitas dalam penelitian ini menggunakan Product Moment dari Pearson. Teknik analisa data sampel responden untuk uji reliabilitas dalam penelitian ini menggunakan teknik Alpha Cronbach's. Semuanya diolah dengan bantuan program SPSS versi 22. Variabel variabel penelitian ini terdiri dari satu 
P-ISSN 2580 - 7781

E-ISSN 2615 - 3238

variabel bebas dan satu variabel terikat. Variabel bebas pada penelitian ini: media sosial (X) sedangkan variabel terikatnya perilaku konsumtif (Y).

Dalam Kuesioner, mahasiswa diminta menjawab kuesioner tersebut dengan metode skala likert. Ada 5 skala yang dicantumkan. Skala satu sangat tidak sesuai, skala dua tidak sesuai, skala tiga biasa, skala empat sesuai dan skala lima sangat sesuai. Penelitian ini ingin menguji hipotesis dimana media sosial berpengaruh positif terhadap perilaku konsumtif mahasiswa.

\section{HASIL PENELITIAN DAN PEMBAHASAN}

Data sampel kuesioner dari responden yang terkumpul total 81 responden. Berikut adalah tabel karakteristik demografik responden :

Tabel 1 Karakteristik Demografik

\begin{tabular}{lllll}
\hline No & Demografik & Jumlah & Persentase \\
\hline $\mathbf{1}$ & Gender & \multicolumn{3}{l}{} \\
& Laki-Laki & 30 & $37 \%$ & \\
& Perempuan & 51 & $63 \%$ & \\
$\mathbf{2}$ & Usia & & & \\
& 21 Tahun & 21 & $25,9 \%$ \\
& 22 Tahun & 40 & $49.4 \%$ \\
& 23 Tahun & 17 & $21 \%$ \\
& 24 Tahun Keatas & 3 & $3.7 \%$ \\
$\mathbf{3}$ & Media Sosial & & \\
& Facebook & 8 & $9.9 \%$ \\
& Instagram & 16 & $19.8 \%$ \\
& Twitter & 2 & $2.5 \%$ \\
& Facebook \& Instagram & 49 & $60.5 \%$ \\
& Facebook, Instagram \& & 6 & $7.4 \%$ \\
& Twitter & & \\
\hline
\end{tabular}

Pada tabel satu tentang data demografik diperoleh hasil untuk responden laki-laki berjumlah 30 atau $37 \%$ dan untuk perempuan berjumlah 51 atau $63 \%$. Berikut data gender dalam bar chart : 


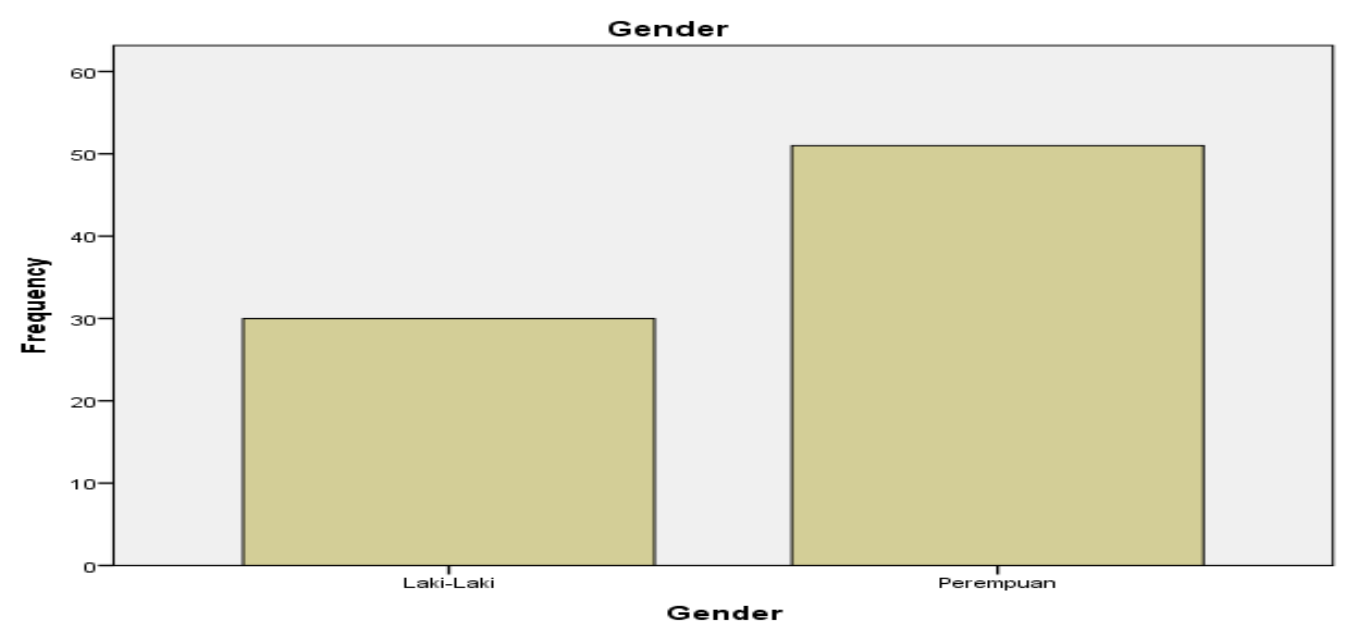

Gambar 1. Bar Chart 1 Gender

Data mengenai usia diperoleh, untuk usia 21 tahun berjumlah 21 atau 25,9\%, untuk usia 22 tahun berjumlah 40 atau 49,4\%, untuk usia 23 tahun berjumlah 17 atau $21 \%$ dan usia 24 tahun keatas berjumlah 3,7\%. Berikut data usia dalam bar chart :

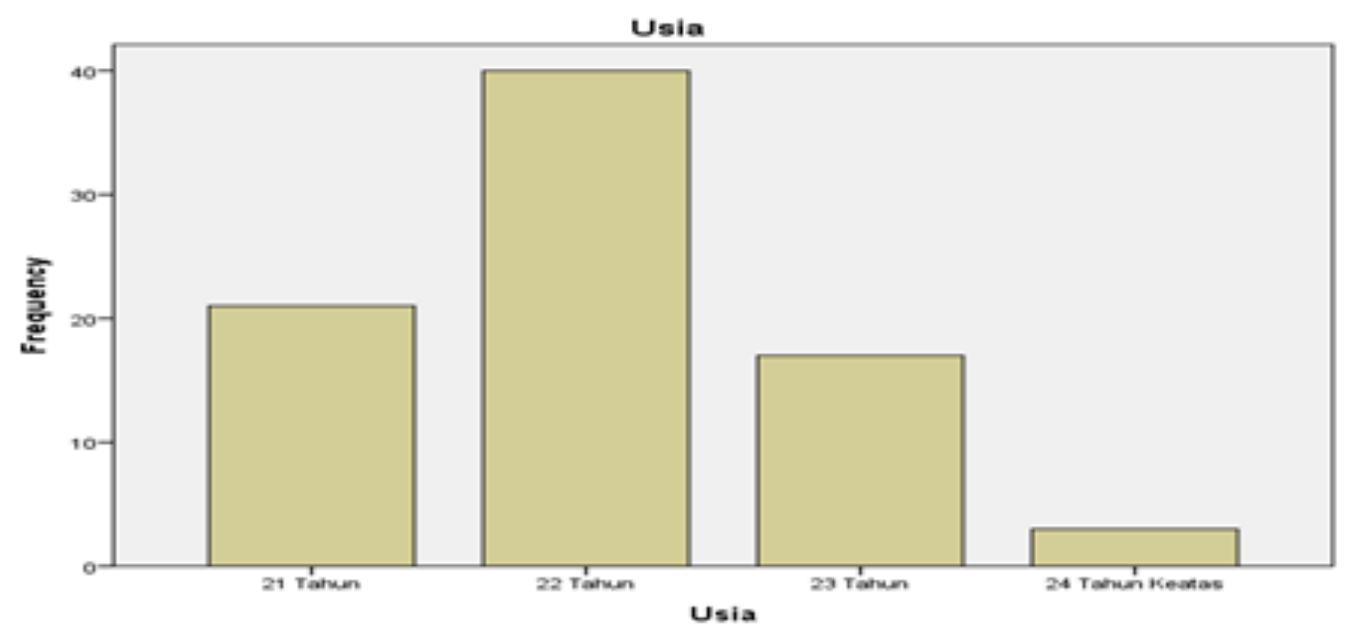

Gambar 2. Bar Chart 2 Usia

Data mengenai media sosial diperoleh sebagai berikut:, mereka yang hanya memiliki akun facebook berjumlah 8 atau 9,9\%. Mereka yang hanya memiliki Instagram berjumlah 16 atau 19,8\%. Mereka yang hanya memiliki twitter berjumlah 2 atau 2,5\%. Mereka yang memiliki akun facebook dan Instagram 
P-ISSN 2580 - 7781

E-ISSN 2615 - 3238

sekaligus berjumlah 49 atau $60,9 \%$ dan mereka yang memiliki facebook, Instagram dan twitter sekaligus sebanyak 6 atau 7,4\%. Berikut data media sosial dalam bar chart :

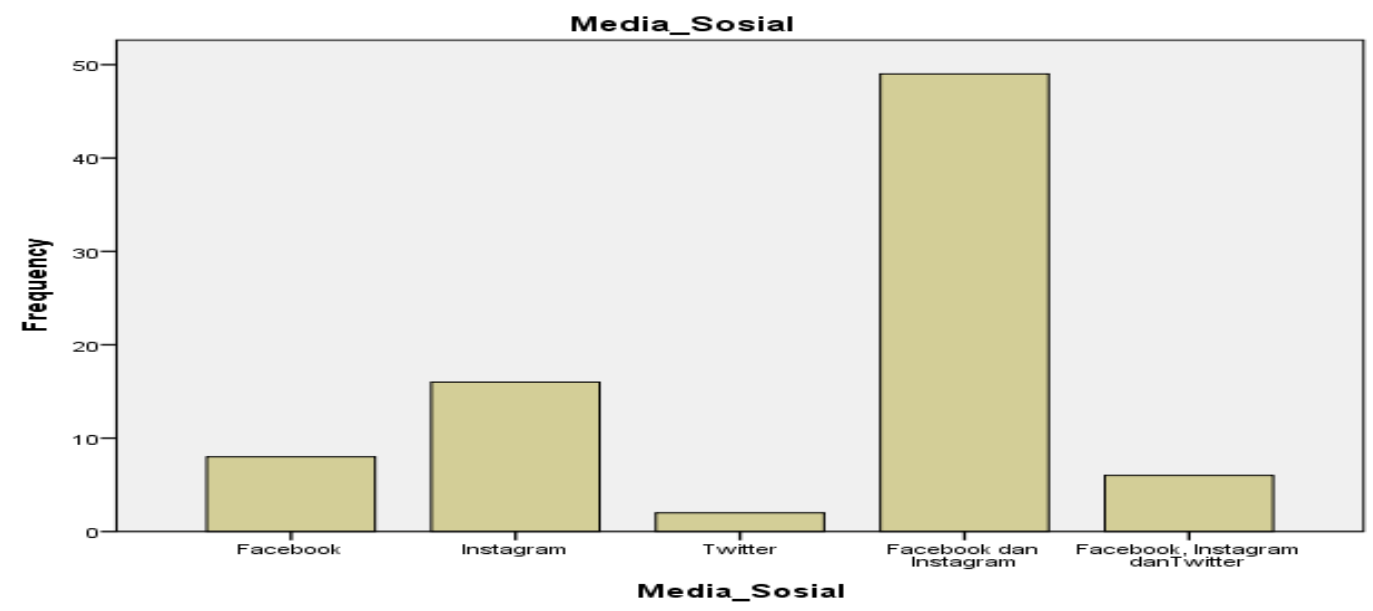

Gambar 3. Bar Chart 3 : Media Sosial

Penulis juga membagikan kuesioner tentang variabel media sosial kepada responden yangakan diuji validitas dan reliabilitasnya. Berikut tabel pertanyaan kuesioner variable $\mathrm{X}$ yang harus diisi oleh responden :

Table 2 Pengaruh Media Sosial (X)

\begin{tabular}{cc}
\hline No & Pertanyaan \\
\hline $\mathbf{1}$ & Anda memiliki akun media sosial \\
$\mathbf{2}$ & Anda memiliki lebih dari satu akun media sosial \\
$\mathbf{3}$ & Anda menggunakan media sosial setiap hari \\
$\mathbf{4}$ & Anda menggunakan media sosial untuk pekerjaan \\
$\mathbf{5}$ & Anda menggunakan media sosial untuk berbelanja \\
$\mathbf{6}$ & Anda menggunakan menggunakan media sosial untuk \\
& belajar \\
$\mathbf{7}$ & Anda menggunakan media sosial untuk mencari berita \\
$\mathbf{8}$ & Anda menggunakan media sosial untuk hiburan \\
\hline
\end{tabular}


P-ISSN 2580 - 7781

E-ISSN 2615 - 3238

\section{Uji validitas Variabel $X$}

Uji validitas digunakan untuk menguji kevalidan angket. Rumusnya nila $r$ hitung lebih besar dari nilai $r$ tabel. Bila $r$ hitung lebih besar dari nilai $r$ tabel maka angket dinyatakan valid. Begitupun sebaliknya.Nilai $r$ tabel untuk kuesioner ini adalah 0,220 dengan nilai signifikansi 5\%.

Berikut hasil uji validitas 8 item kuesioner variable $\mathrm{X}$ media sosial dengan menggunakan SPSS 22 :

Tabel 3 Hasil Uji Validitas Media Sosial (X)

\begin{tabular}{rrrl}
\hline Item & r hitung & r tabel & Hasil \\
\hline $\mathbf{1}$ & 0,262 & 0,220 & valid \\
$\mathbf{2}$ & 0,389 & 0,220 & valid \\
$\mathbf{3}$ & 0,286 & 0,220 & valid \\
$\mathbf{4}$ & 0,500 & 0,220 & valid \\
$\mathbf{5}$ & 0,625 & 0,220 & valid \\
$\mathbf{6}$ & 0,519 & 0,220 & valid \\
$\mathbf{7}$ & 0,294 & 0,220 & valid \\
$\mathbf{8}$ & 0,319 & 0,220 & valid \\
\hline
\end{tabular}

Hasil uji validitas pada tabel 3 semua item uji validitas variable $X$ nilainya lebih besar dari r tabel. Kesimpulannya 8 item data kuesioner dinyatakan valid.

\section{Uji Reliabilitas Variabel X}

Uji reliabilitas bertujuan untuk melihat konsistensi angket. Rumusnya adalah nilai alpha lebih besar dari nilai $r$ tabel. Bila nilai alpha lebih besar dari nilai $\mathrm{r}$ tabel maka angket dinyatakan reliabel. Berikut hasil uji reliabilitas menggunakan SPSS 22 : 
Table 4 Hasil Uji Reliabilitas Variabel (X)

\begin{tabular}{ll}
\hline Cronbach Alpha & Item \\
\hline $\mathbf{0 , 2 7 2}$ & 8 \\
\hline
\end{tabular}

Dari hasil uji reliabilitas didapatkan hasil nilai alpha lebih besar dari nilai $r$ tabel, yakni nilai alpha 0,272 lebih besar dari $r$ tabel 0,220. Maka kesimpulannya 8 item data kuesioner variabel $\mathrm{X}$ dinyatakan reliabel.

Penulis juga membagikan kuesioner variable $\mathrm{Y}$ tentang perilaku konsumtif mahasiswa kepada responden yang nanti akan diuji validitas dan reliabilitasnya. Berikut tabel pertanyaan kuesioner variable $\mathrm{Y}$ yang harus diisi oleh responden.

Tabel 5. Perilaku Konsumtif Mahasiswa(Y)

\begin{tabular}{ll}
\hline No & Pertanyaan \\
\hline $\mathbf{1}$ & Pencarian informasi belanja lebih mudah dengan media sosial \\
$\mathbf{2}$ & Iklan di media sosial mempengaruhi saya untuk berbelanja \\
$\mathbf{3}$ & Berbelanja di media sosial memberikan banyak diskon \\
$\mathbf{4}$ & Berbelanja di media sosial lebih menghemat waktu \\
$\mathbf{5}$ & Berbelanja di media sosial lebih banyak pilihan \\
$\mathbf{6}$ & Media sosial membuat intensitas belanja meningkat \\
$\mathbf{7}$ & Media sosial berpengaruh terhadap keuangan anda \\
$\mathbf{8}$ & Pendapatan selalu anda sisihkan untuk belanjda di media sosial \\
\hline
\end{tabular}

\section{Uji validitas Variabel Y}

Uji validitas digunakan untuk menguji kevalidan angket. Rumusnya nilai $r$ hitung lebih besar dari nilai $r$ tabel. Bila $r$ hitung lebih besar dari nilai $r$ tabel maka angket dinyatakan valid. Begitupun sebaliknya.Nilai $r$ tabel untuk kuesioner ini adalah 0,220 dengan nilai signifikansi $5 \%$.

Berikut hasil uji validitas 8 item kuesioner variable Y media sosial dengan menggunkan SPSS 22: 
Tabel 6. Hasil Uji Validitas Perilaku Mahasiswa (Y)

\begin{tabular}{llll}
\hline Item & r hitung & r tabel & Hasil \\
\hline $\mathbf{1}$ & 0,273 & 0,220 & valid \\
$\mathbf{2}$ & 0,567 & 0,220 & valid \\
$\mathbf{3}$ & 0,441 & 0,220 & valid \\
$\mathbf{4}$ & 0,427 & 0,220 & valid \\
$\mathbf{5}$ & 0,480 & 0,220 & valid \\
$\mathbf{6}$ & 0,523 & 0,220 & valid \\
$\mathbf{7}$ & 0,470 & 0,220 & valid \\
$\mathbf{8}$ & 0,555 & 0,220 & valid \\
\hline
\end{tabular}

Dari hasil uji validitas didapat semua item nilainya lebih besar dari $\mathrm{r}$ tabel. Maka kesimpulannya 8 item data kuesioner variable Y dinyatakan valid.

\section{Uji Reliabilitas Variabel Y}

Uji reliabilitas bertujuan untuk melihat konsistensi angket. Rumusnya adalah nilai alpha lebih besar dari nilai $r$ tabel. Bila nilai alpha lebih besar dari nilai $\mathrm{r}$ tabel maka angket dinyatakan reliabel. Berikut hasil uji reliabilitas menggunakan SPSS 22 :

Table 7. Hasil Uji Reliabilitas Variabel (Y)

\begin{tabular}{ll}
\hline Cronbach Alpha & Item \\
\hline $\mathbf{0 , 5 2 8}$ & 8 \\
\hline
\end{tabular}

Dari hasil uji reliabilitas didapatkan hasil nilai alpha lebih besar dari nilai $r$ table, yakni nilai alpha 0,528 lebih besar dari $r$ table 0,220. Maka kesimpulannya data kuesioner variabel Y dinyatakan reliabel.

Setelah uji validitas dan reliabilitas variable $\mathrm{X}$ dan $\mathrm{Y}$ maka selanjutnya penulis melakukan uji analisis korelasi person. Rumusnya bila nilai signifikansi lebih kecil dari 0,05 maka terdapat korelasi, begitu pun sebaliknya bila nilai signifikansi lebih besar dari 0,05 maka tidak terdapat korelasi. 
P-ISSN 2580 - 7781

E-ISSN 2615 - 3238

Rumusnya :

- Jika nilai signifikansi $<0.05$ artinya ada korelasi

- Jika nilai signifikansi > 0.05 artinya tidak ada korelasi

Berikut hasil uji korelasi dengan menggunakan SPSS 22 :

Tabel 8. Hasil Uji Korelasi

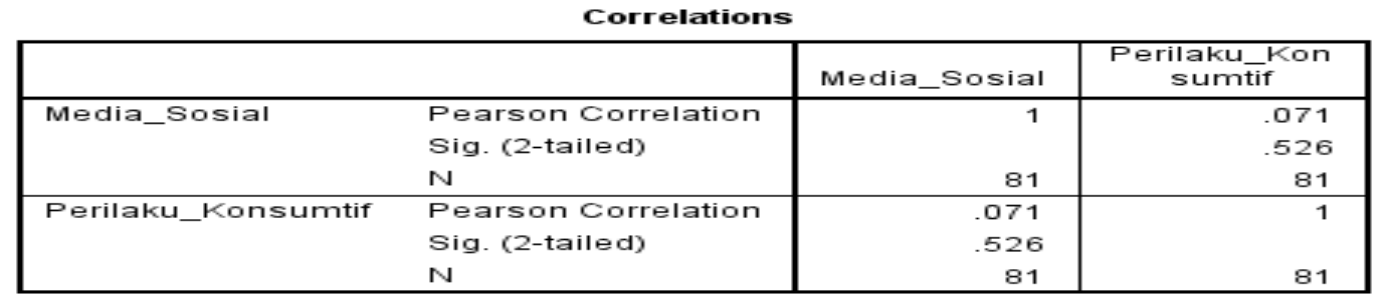

Dari hasil uji korelasi didapatkan nilai signifikansi 0,526 lebih besar dari 0,05 artinya tidak ada korelasi antara media sosial terhadap perilaku konsumtif mahasiswa.

Hasil dari uji korelasi bisa dipahami bahwa media sosial tidak selalu berpengaruh negatif seperti makin konsumtifnya belanja mahasiswa. Hal ini dapat dimengerti bahwa keuangan mahasiswa tentu berbeda dengan mereka yang sudah mapan secara ekonomi. Kita ketahui bersama usia setingkat mahasiswa tentu masih mengandalkan uang jajan dari orang tuanya. Sehingga kemungkinan kecil mereka akan menghamburkan uang untuk belanja di media sosial. Kalaupun mereka belanja kebutuhan di media sosial mungkin ukurannya karena butuh akan barang tersebut bukan sekedar keinginan. Apalagi seusia mereka tentu kebutuhan hidupnya tidak terlalu banyak seperti mereka yang sudah berumah tangga.

\section{Uji Hipotesis}

Dalam uji t diketahui nilai Sig untuk pengaruh $\mathrm{X}$ terhadap $\mathrm{Y}$ sebesar 0,526>0,05 artinya nilai Sig lebih besar dari 0,05 atau nilai t hitung 0,071 < r tabel 0.220 artinya nilai t hitung lebih kecil dari t tabel maka dapat disimpulkan bahwa $\mathrm{H}$ ditolak yang berarti tidak terdapat pengaruh variabel $\mathrm{X}$ terhadap $\mathrm{Y}$. 
P-ISSN 2580 - 7781

E-ISSN 2615 - 3238

Hasilnya bisa kita ketahui bersama bahwa media sosial sebagai variable $\mathrm{X}$ tidak berpengaruh signifikan terhadap pola perilaku konsumtif mahasiswa sebagai variable $Y$.

\section{KESIMPULAN}

Dari pembahasan diatas dapat disimpulkan bahwa media sosial tidak berpengaruh signifikan terhadap perilaku konsumtif mahasiswa. Keterbatasan uang jajan dan kebutuhan hidup yang tidak terlalu banyak boleh jadi menjadi alasannya. Meskipun hal tersebut tidak bisa jadikan patokan utama. Karena boleh jadi memang karakter responden tidak suka dengan gaya hidup konsumtif.

Artikel ini hanya melihat melihat media sosial sebagai rujukan utama dari perilaku konsumtif mahasiswa. Masih banyak faktor lain yang bisa di uji untuk mengetahui faktor-faktor yang menjadi pendorong mahasiswa berperilaku konsumtif.

\section{DAFTAR PUSTAKA}

Agnihotri, R., Dingus, R., Hu, M. Y., \& Krush, M. T. (2016). Social media: Influencing customer satisfaction in B2B sales. Industrial Marketing Management, 53 , $172-180$. https://doi.org/10.1016/j.indmarman.2015.09.003

Anggraini, R. T., \& Santhoso, F. H. (2019). Hubungan antara Gaya Hidup Hedonis dengan Perilaku Konsumtif pada Remaja. Gadjah Mada Journal of Psychology (GamaJoP), 3(3), 131. https://doi.org/10.22146/gamajop.44104

Das, A. C. (2014). International Journal of Research ( Ijr ). 2(4), 548-577.

Delafrooz, N., Zendehdel, M., \& Fathipoor, M. (2017). The Effect of Social Media on Customer Loyalty and Company Performance of Insurance Industry. International Journal of Economics and Financial Issues, 7(3), 254-264.

Empati, J., Nomor, V., Antara, H., Diri, K., Perilaku, D., Tripambudi, B., \& Indrawati, E. S. (2018). Hubungan Antara Kontrol Diri Dengan Perilaku Konsumtif Pembelian Gadget Pada Mahasiswa Teknik Industri Universitas Diponegoro. Empati, 7(2), 189-195.

Fathelrahman, E., \& Basarir, A. (2018). Use of Social Media to Enhance Consumers' Options for Food Quality in the United Arab Emirates (UAE). Urban Science, 2(3), 70. https://doi.org/10.3390/urbansci2030070

Hajli, M. N. (2013). Compressed-PDF. International Journal o $f$ Market Research, 53(6), 387-404. https://doi.org/10.2501/U M R-2014-025

Is, W., Should, W., \& Be, I. T. (2011). What Is Correlational Research ,. In History. 
Khatib, F. (2016). The Impact of Social Media Characteristics on Purchase Decision Empirical Study of Saudi Customers in Aseer Region. International Journal of Business and Social Science, 7(4), 41-50. https://doi.org/10.1016/j.tourman.2012.11.009

Lee, E. (2013). Impacts of Social Media on Consumer Behavior- Decision Making Process. Bachelor's Thesis, 1-77.

Perdana. (2018). 済無No Title No Title. Journal of Chemical Information and Modeling, 53(9), 1689-1699. https://doi.org/10.1017/CBO9781107415324.004

POTURAK, M., \& SOFTIĆ, S. (2019). Influence of Social Media Content on Consumer Purchase Intention: Mediation Effect of Brand Equity. Eurasian Journal of Business and Economics, 12(23), 17-43. https://doi.org/10.17015/ejbe.2019.023.02

Pradeep, S., \& Nair, C. (2018). Impact of social media on consumer buying decision towards financial assets among it professionals at kerala. International Journal of Mechanical Engineering and Technology, 9(6), 916-921.

Rizkallah, E. G., \& Truong, A. (2010). Preferences , And Shopping Patterns. 8(1).

Voramontri, D., \& Klieb, L. (2019). Impact of social media on consumer behaviour. International Journal of Information and Decision Sciences, 11(3), 209-233. https://doi.org/10.1504/IJIDS.2019.101994

Widyaningrum, S., \& Puspitadewi, N. (2016). Perbedaan Perilaku Konsumtif Ditinjau dari Tipe Kepribadian Pada Siswa Sekolah Menengah Atas Sandra Widyaningrum, Ni Wayan Sukmawati Puspitadewi Program Studi Psikologi Universitas Negeri Surabaya. Jurnal Psikologi Teori Dan Terapan, 6(2), 102-106. Retrieved from https://docplayer.info/67563592-Perbedaanperilaku-konsumtif-ditinjau-dari-tipe-kepribadian-pada-siswa-sekolahmenengah-atas.html 